\title{
Graptemys oculifera (Baur 1890) - Ringed Map Turtle, Ringed Sawback
}

\author{
Robert L. Jones ${ }^{1}$ ANd Will Selman ${ }^{2}$ \\ ${ }^{1}$ Mississippi Department of Wildlife, Fisheries, and Parks, Museum of Natural Science, \\ 2148 Riverside Drive, Jackson, Mississippi 39202 USA [bob.jones@mmns.state.ms.us]; \\ ${ }^{2}$ Department of Biological Sciences, The University of Southern Mississippi, \\ 118 College Drive \#5018, Hattiesburg, Mississippi 39406 USA [will.selman@usm.edu]
}

Summary. - The ringed map turtle, Graptemys oculifera (Family Emydidae), is a medium-sized aquatic turtle that inhabits the Pearl River watershed of Mississippi and Louisiana. This species prefers larger rivers with current and abundant basking structure in the form of deadwood. Males (carapace length to $109 \mathrm{~mm}$ ) are much smaller than females (to $215 \mathrm{~mm}$ ) and mature between 2 and 4 yrs of age, with females maturing between 10 and 16 yrs. Nesting occurs primarily on sandbars from May to July, average clutch size is 3.66 eggs, clutch size ranges from 1 to 10 , and annual clutch frequency is 1.10. Nest predation is relatively high, with ca. $86 \%$ destroyed by vertebrate predators, usually raccoons, fish crows, or armadillos. The diet is composed primarily of aquatic insects. Densities range from 90 to over 340 turtles per river $\mathbf{~ k m}$. Primary threats appear to be habitat loss, modification, and sedimentation. The current IUCN status as Endangered should be retained primarily because of the restricted distribution of this species and the continuing loss of habitat within that restricted range.

Distribution. - USA. Restricted to the Pearl River drainage of Mississippi and Louisiana.

Synonymy. - Malacoclemmys oculifera Baur 1890, Graptemys oculifera, Malaclemys lesueurii oculifera, Graptemys pseudogeographica oculifera, Graptemys oculifera oculifera, Malaclemys oculifera.

SuBSPECIES. - None currently recognized.

STATUS. - IUCN 2009 Red List: Endangered (EN B1+2c) (assessed 1996, needs updating); CITES: Appendix III (as Graptemys spp., USA); US ESA: Threatened.

Taxonomy. - The ringed map turtle was described as Malacoclemmys oculifera by Baur (1890) based on a series of specimens sent by Gustave Kohn from New Orleans to the United States National Museum. The labels on these specimens indicated that they were from Mandeville, Loui- siana and Pensacola, Florida, and the Louisiana specimens (USNM 15508, 15509, 15510, 15511, listed as syntypes in the USNM database) were considered the types (Baur 1890). Baur (1893) later transferred this species to the genus Graptemys. Stejneger and Barbour (1933) listed the

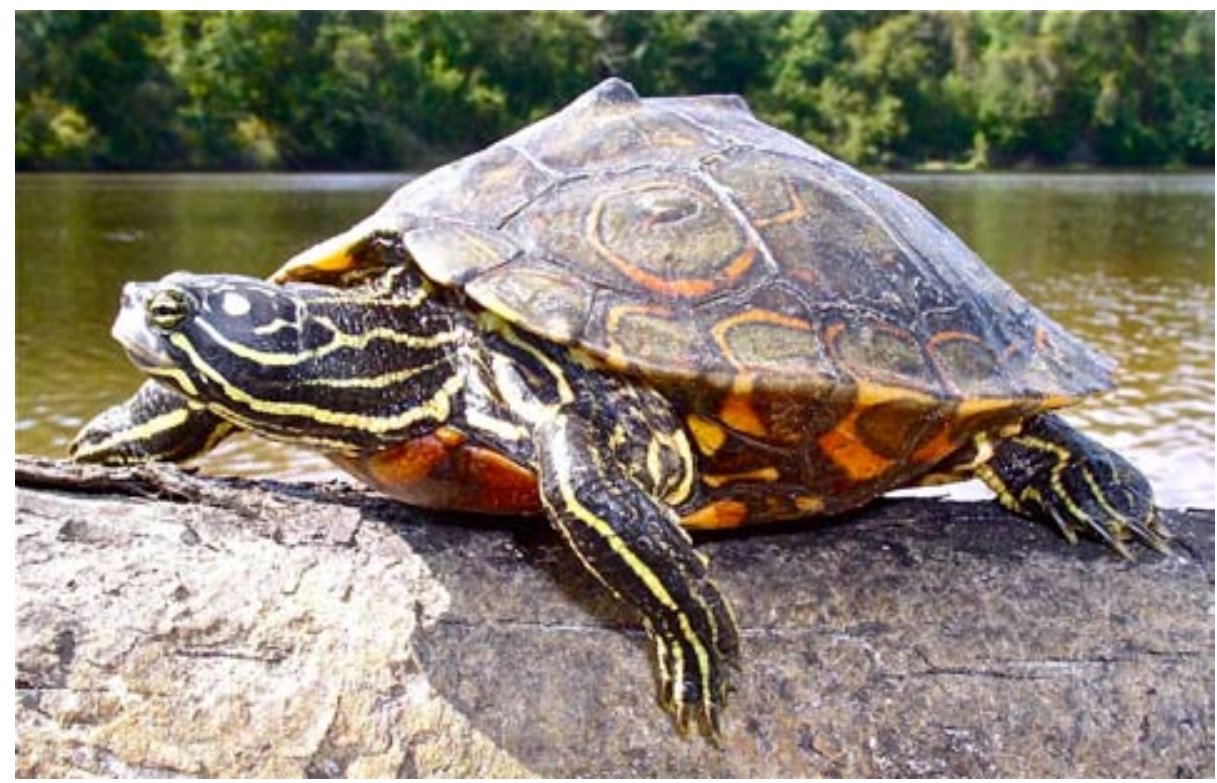

Figure 1. Adult female Graptemys oculifera from the Pearl River, Mississippi. Photo by Robert L. Jones. 


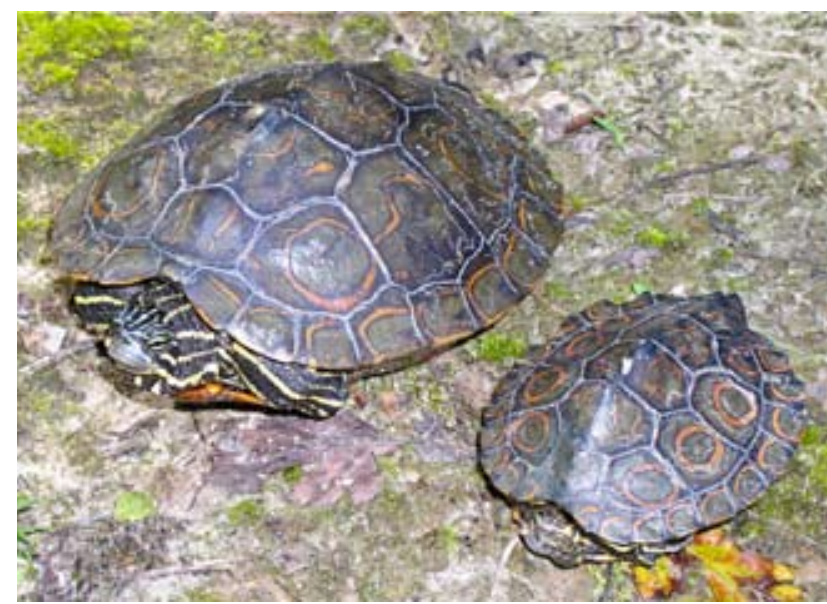

Figure 2. Sexual size dimorphism in Graptemys oculifera. Adult female (left), adult male (right). Photo by Robert L. Jones .

species as Graptemys pseudogeographica oculifera in the third edition of their checklist but as Graptemys oculifera in the fourth (Stejneger and Barbour 1939). Carr (1949) considered the type series to represent variants of Graptemys pseudogeographica kohnii. Cagle (1953) reassessed the species based on new material and concluded that it was a distinct species. McDowell (1964) synonymized Graptemys with Malaclemys, but Killebrew (1979) and Dobie (1981) concluded that Graptemys was clearly separable from Malaclemys, and most subsequent authors (e.g., Ernst and Barbour 1989; Ernst et al 1994; Buhlmann et al. 2008; Ernst and Lovich 2009) have followed that arrangement.

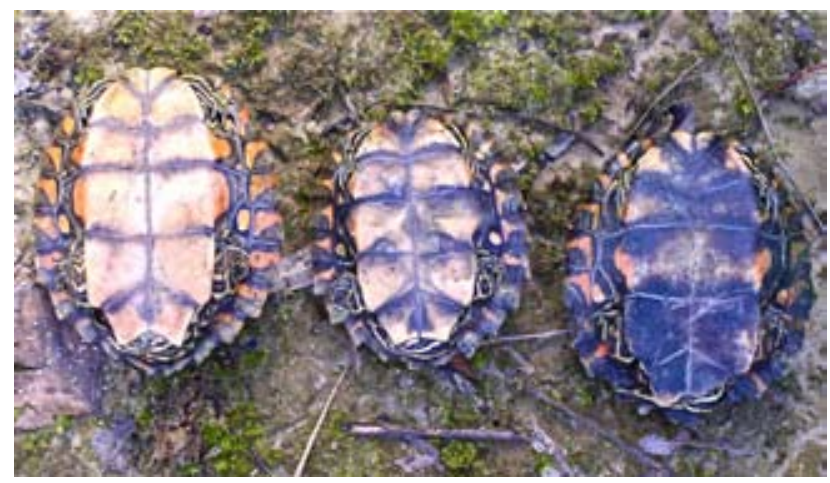

Figure 4. Variation in plastral pigmentation of adult male Graptemys oculifera collected from the same locality. Photo by Robert L. Jones.

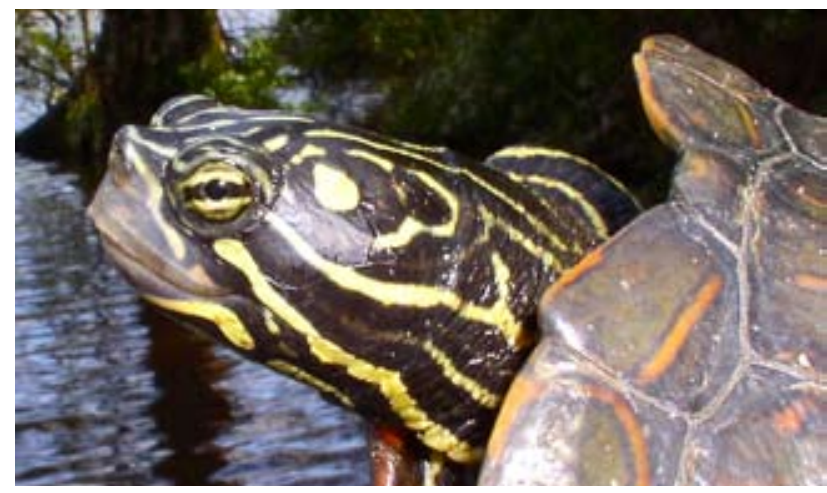

Figure 5. Detail of the head pattern of an adult female Graptemys oculifera. Photo by Robert L. Jones.

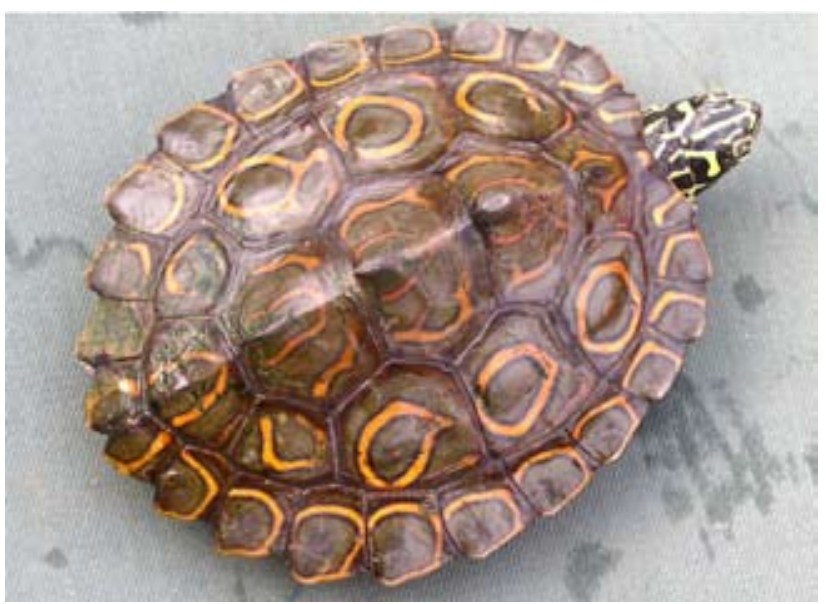

Figure 3. Detail of the carapace pattern of an adult male Graptemys oculifera. Photo by Robert L. Jones.

Lamb et al. (1994) examined mitochondrial DNA restriction sites and sequences in Graptemys and resolved three monophyletic clades. Graptemys oculifera was placed in the pseudogeographica clade with G. flavimaculata as its sister species.

Description. - Adult female G. oculifera (Fig. 1) have an average carapace length (CL) of $156 \mathrm{~mm}$ and range from 130-215 mm (Jones 2006). Adult males are much smaller (Fig. 2), averaging $89 \mathrm{~mm} \mathrm{CL}$, and ranging from 72-109 $\mathrm{mm}$ (Jones, unpubl. data). The carapace is longer than wide in both sexes (mean width $128 \mathrm{~mm}$ in adult females and 75 $\mathrm{mm}$ in adult males; Jones, unpubl. data). Although variation in adult sizes has been documented at different locations in the Pearl River (Jones and Hartfield 1995), there do not appear to be any geographic trends in body size variation in this species.

The carapace is moderately domed, has a median keel, and has laterally compressed, spine-like projections on vertebrals one through four. The projections on the second and third vertebrals are larger and may be almost vertical to directed moderately to the posterior, while those on vertebrals one and four are much smaller and directed strongly posteriorly. Projections in older females tend to be rounded and much less pronounced than in adult males or juveniles.

The ground color of the carapace ranges from light olive to dark green. Marginals usually have a moderately wide,

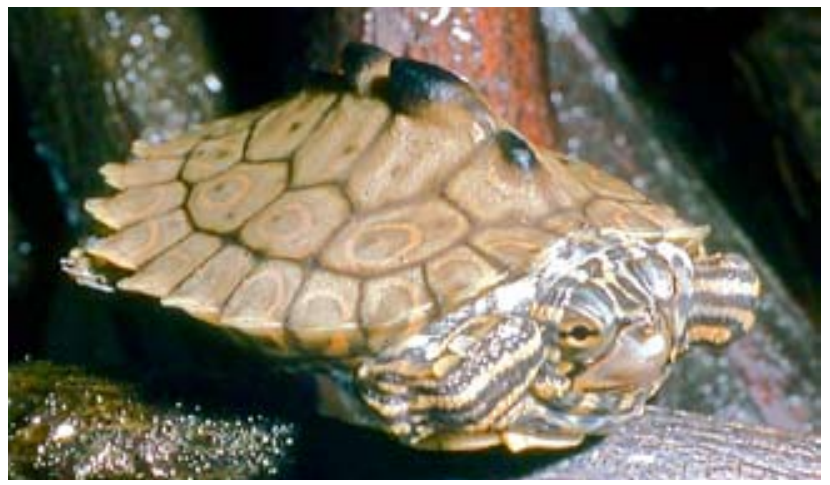

Figure 6. Hatchling Graptemys oculifera from the Pearl River, Mississippi. Photo by Robert L. Jones. 


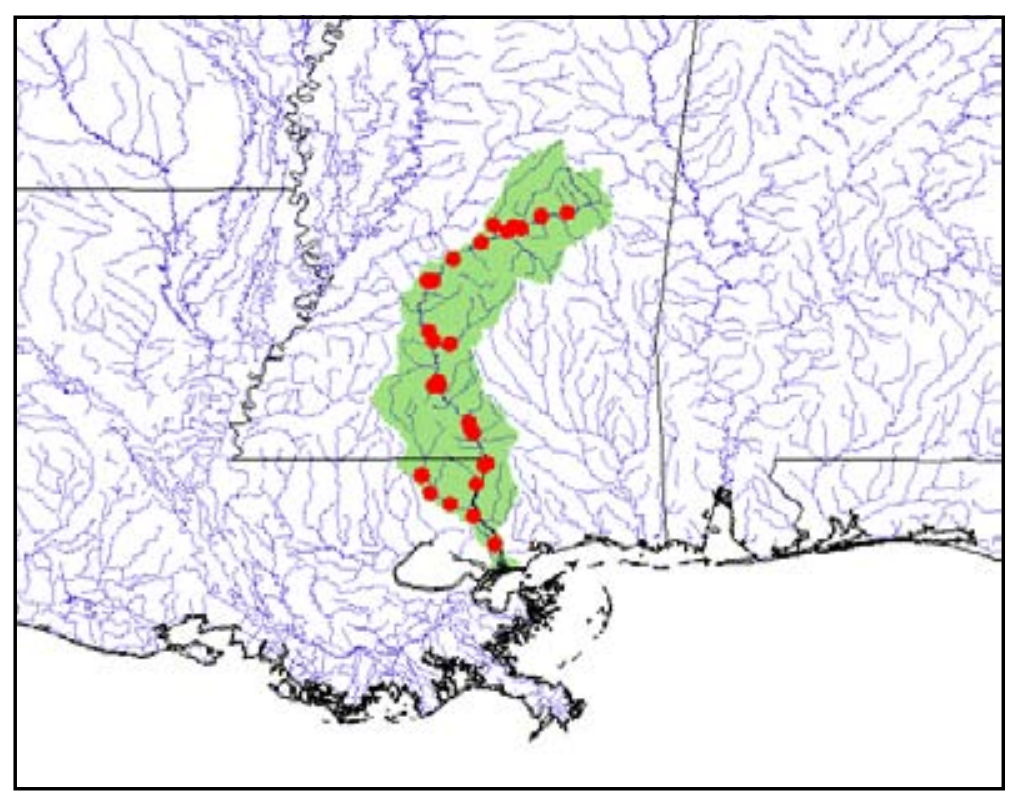

Figure 7. Distribution of Graptemys oculifera in southeastern USA (Mississippi and Louisiana). Red points = museum and literature occurrence records based on Iverson (1992) plus more recent and authors' data; green shading = projected distribution based on GISdefined hydrologic unit compartments (HUCs) constructed around verified localities and then adding HUCs that connect known point localities in the same watershed or physiographic region, and similar habitats and elevations as verified HUCs (Buhlmann et al., in press), and adjusted based on authors' data.

broken ring that varies from pale yellow to bright orange (Fig. 3). The rings usually extend from the outside anterior margin back toward the interior margin of the scute and then curve sharply posteriorly before ending on the posterior margin. These rings are sometimes reduced to bars and occasionally occur as complete rings that may have a small bar or spot in the center, especially in juveniles. The underside of each marginal has yellow pigment covering one-half to two thirds of the scute, while the remainder is dark.

Each costal scute usually has a ring that is somewhat wider than, but of the same color as, the rings on the marginals (Fig. 3). Some rings may have an extension in the form of a short bar that projects either anteriorly or posteriorly. The rings are occasionally broken or may be reduced to two curved bars, particularly on the fourth costal. Occasionally, costal rings are reduced to a single bar or a small blotch.

The vertebral spines are tipped with black, and are usually closely flanked laterally by curved yellow or orange bars. The lateral portions of the vertebral scutes, particularly scutes two through four, commonly have bars or broken rings.

The plastron is yellow with varying amounts of dark pigment along the seams. In some individuals, the plastron may be almost entirely pigmented (Fig. 4). The axillary scute usually has a large yellow spot on its anterior end and a yellow ventral bar, or occasionally a yellow ventral spot. The inguinal scute usually has a relatively large, yellow posterior spot and a yellow ventral bar or spot.

The head (Fig.5) is dark brown to black with yellow stripes. There is an irregularly circular to oblong yellow blotch behind the eye that is usually equal to or smaller than the diameter of the orbit. The blotch may be either connected or not to stripes on the head. There are one or two narrow, curved or broken yellow stripes just posterior to the blotch.

The top of the head (Fig. 3) has one relatively wide yellow central stripe that usually runs from the tip of the snout to just behind the eyes. This stripe is flanked by two yellow stripes on the lateral margins of the top of the head that extend from the front of the head back onto the neck. The lateral head stripes may or may not connect with the central stripe. The lateral stripes, as they extend onto the neck, may be broken, may cross, or may fork. The sides of the head have two prominent yellow stripes that run from the eye onto the neck. There may be a thinner yellow stripe on the neck between the two prominent stripes. There are also one or two short, thin, yellow stripes located on the neck between the stripes originating on the top of the head and the stripes running from the eye backward to the neck.

The chin has a prominent yellow bar that curves backward and extends just posterior to the angle of the jaw. There is sometimes a second thinner yellow bar, or broken bar, just posterior to the chin bar. Posterior to this are two relatively prominent yellow stripes, which may be separate or joined anteriorly and which extend posteriorly onto the neck. There is usually a narrower, fainter yellow stripe between the two that may or may not be broken.

Both the front and rear legs have two prominent yellow stripes dorsally, one to two laterally, and one to two ventrally. There are usually thinner stripes between the prominent stripes. Each toe has a relatively prominent yellow stripe on its dorsal surface. The bottoms of the feet have various bars and spots. The tail has one to two prominent dorsal stripes and one to two prominent ventrolateral stripes. All striping on the legs and tail may be separate or may be joined at various points along their lengths. 
Cagle (1952, 1953) found that the skull of G.oculifera, particularly that of females, was less robust and lacked the strong ridges, projecting shelves, and broadened alveolar surfaces found in other Graptemys species. Killibrew (1979) noted that ridges, shelves, and broadening of the maxillae and skull found in the broad-headed Graptemys were not found in the narrow-headed species, which includes $G$. oculifera.

Sexual dimorphism is pronounced in G. oculifera (Fig. 2). Females are larger (average CL 156 mm, range 130-215 $\mathrm{mm}$ ) and have a more rounded carapace with relatively smaller vertebral spines than males (average CL $89 \mathrm{~mm}$, range 72-109 $\mathrm{mm}$ ) (Jones, unpubl. data). Males have longer foreclaws and greater relative tail lengths.

The ground color of the carapace of hatchling $\mathrm{G} . \mathrm{ocu}$ lifera is grayer than in adults (Fig. 6), but in general they are similar in color and markings to adults, particularly adult males. The vertebral spines on the carapace tend to be directed posteriorly to a greater degree than in most adults. Hatchlings are nearly round, with a mean CL of $36 \mathrm{~mm}$ (Jones 2006) and a mean width of $35 \mathrm{~mm}$ (Jones, unpubl. data).

The three species of Graptemys (flavimaculata, nigrino$d a$, oculifera), which are often referred to as the "sawback" group, can be distinguished from the other species in the genus by their higher vertebral ridges and prominent vertebral spines (Buhlmann et al. 2008). Cagle (1954) outlined a series of characters that may be used to differentiate the three sawback species. The vertebral projections of $G$. nigrinoda are relatively broad and knob-like, while those of the other two species are laterally compressed and more spine-like. Graptemys oculifera is distinguished from $G$. flavimaculata primarily by the markings on the costals: the former usually has relatively broad rings, while the latter usually has a solid blotch. However, some G. flavimaculata, particularly those from the Escatawpa River, can have rings on some or all of their costal scutes.

Other characters that may serve to differentiate these two species are coloration of the marginal and vertebral scutes and coloration of the soft parts. The ringed map turtle usually has narrow yellow bars on the vertebrals, while $G$. flavimaculata has wide yellow blotches and bars. The dorsal and ventral surfaces of the marginals in G. flavimaculata have wide yellow to orange bars, while those on the marginals of G. oculifera are narrow. The stripes on the soft parts of $G$. oculifera are usually relatively narrower than the dark spaces between them, while those of G. flavimaculata are usually wider than the dark spaces between them, giving the latter species an overall yellower appearance.

Distribution. - The ringed map turtle is found only in the Pearl River watershed of Mississippi and Louisiana, where it occurs primarily in the Pearl River and its largest tributary, the Bogue Chitto River(Fig. 7). The most northerly confirmed location in Mississippi is the Pearl River ca. 5.6 $\mathrm{km}$ northeast of the Mississippi Highway 15 crossing south of Burnside, Neshoba County (Keiser 2000). The southernmost locality is in the West Pearl River north of I-10, St.
Tammany Parish, Louisiana (McCoy and Vogt 1980). It has also been observed in the Pearl River just north of Napoleon, Hancock County, Mississippi (Jones, pers. obs.). Shively (1999) found the ringed map turtle throughout the Bogue Chitto River in Louisiana, and speculated that its upstream limit in that system might be somewhere in southern Walthall County, Mississippi. However, this species has not yet been observed in the Bogue Chitto River in Mississippi.

The ringed map turtle has been reported from only a few smaller tributaries of the Pearl River in Mississippi (Strong River, Copiah Creek, McCoy and Vogt 1980; Yockanookany River, Strong River, Lindeman 1998) and Louisiana (Porter River, Kofron 1991).

Habitat and Ecology. - The ringed map turtle is primarily an inhabitant of the larger streams and rivers within the Pearl River watershed, where it is most common within the main stem of the Pearl River (Fig. 8a). Most descriptions of the habitat of this species (McCoy and Vogt 1980; McCoy and Vogt 1988; Dundee and Rossman 1989; Dickerson and Reine 1996; Lindeman 1999; Buhlmann et al. 2008) have noted fast to moderate currents, the presence of numerous basking logs, the presence of sandbars used for nesting, and a channel wide enough to allow sunlight to penetrate to the surface for much of the day.

Jones and Hartfield (1995) studied populations at five locations along the Pearl River in Mississippi, and at these sites the river ranged from 20 to $110 \mathrm{~m}$ in width, mean

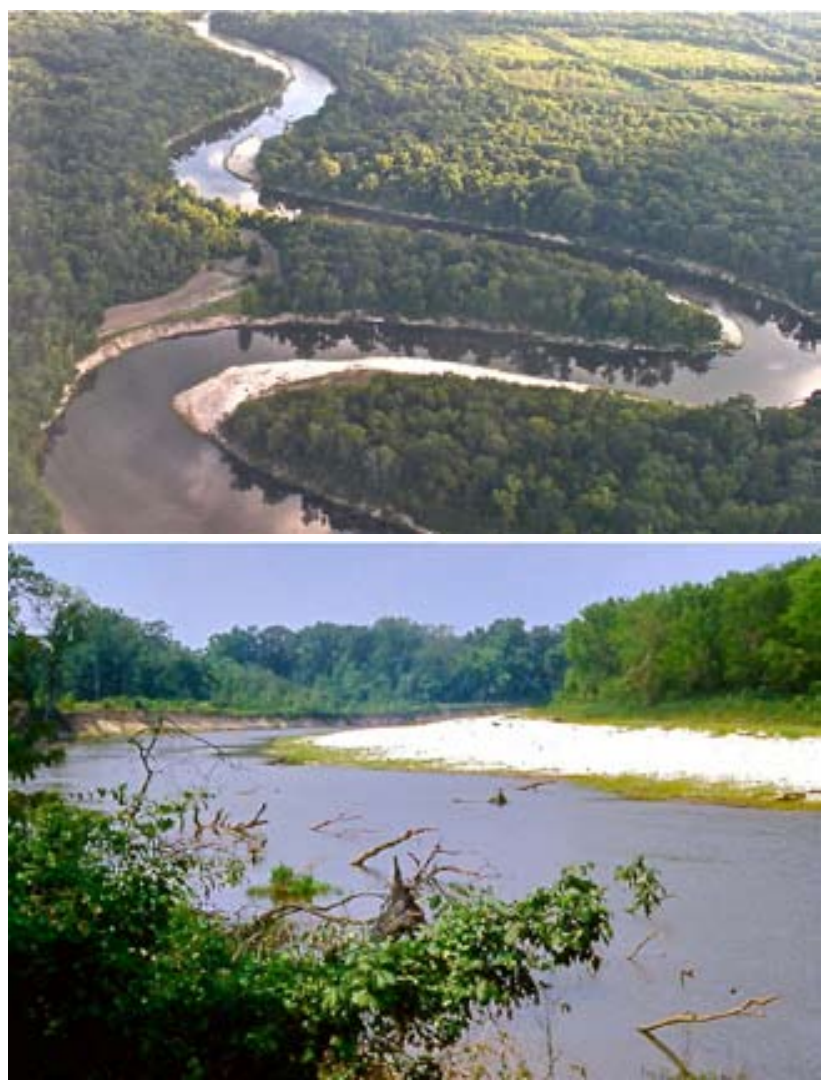

Figure 8. Top (a): Pearl River, Mississippi, showing typical habitat of Graptemys oculifera. Bottom (b): Lateral sandbar where G. oculifera nests, and deadwood used for basking in the channel of the Pearl River. Photos by Robert L. Jones. 
stream flow rates ranged from 3000 to $15000 \mathrm{cfs}$, and the river bottom was composed of clay, sand, or gravel. All sites also had abundant logs or treetops for basking, and sandbars that ranged from large lateral and point bars to small lateral bars (Fig. 8b).

Although this species prefers large river habitats, it is occasionally found in other areas as well. Kofron (1991) reported a specimen from an oxbow near the Pearl River, and Keiser (1994) observed several G. oculifera in gravel pit ponds near the Pearl River at the Stennis Space Center in Hancock County, Mississippi. This species has been observed in oxbows connected to the Pearl River at Ratliff Ferry, Rankin County, Mississippi, and in oxbows not connected to the Pearl River at LeFleur's Bluff State Park, Hinds County, Mississippi (Lindeman 1998; Jones, pers. obs). In the latter case, it is assumed that the turtles reached the oxbow during river flooding and remained there after flood waters receded. McCoy and Vogt (1980) and Lindeman (1998) also reported G. oculifera from Ross Barnett Reservoir, a water supply reservoir on the Pearl River north of Jackson, Mississippi. Although individuals move into or may be transported into this reservoir from upstream during floods, there is no evidence that a breeding population inhabits this body of water.

Growth, Sexual Maturity, and Longevity. - Jones and Hartfield (1995) produced growth curves for both males and females of this species using the von Bertalanffy model and recapture data. Growth is approximately equal for the two sexes during the first two to three years of life. Male growth rate then slows with the onset of sexual maturity, while female growth rate continues at or near the juvenile rate until sexual maturity is reached. Based on these growth curves, males were hypothesized to mature at a plastron length of ca. 60-70 mm (CL of 72-83 mm; Jones, unpubl. data) and an age of 2.5-4.5 yrs. Females were hypothesized to mature at 10-16 yrs of age at a plastron length of ca. 115-120 mm (corresponding to a CL of 130-140 mm; Jones 2006).

Longevity of G.oculifera has notbeen studied.However, both male and female turtles marked between 1988 and 1990 (Jones and Hartfield 1995) were recaptured as recently as 2009. Several of these turtles were adults when first marked in 1988 , so their minimum ages, assuming male maturity at 2.5-4.5 years and female maturity at 10-16 years, would be 23.5-25.5 yrs for the males and 31-37 yrs for the females.

Reproduction and Nesting. - Unless otherwise indicated, data on reproduction, nesting, clutch size, egg size, incubation period, nesting success, and nest predators are from Jones (2006). Maximum testes size in male G.oculifera occurs during August and September, so spermatogenesis is assumed to occur at that time (Kofron 1991). Nesting occurs from mid-May to mid-July over a period of ca. 67 days, and nests are placed primarily on sandbars (Fig. 8b) ranging in size from about 40 to over $9000 \mathrm{~m}^{2}$. The surface areas of these sandbars averaged $39 \%$ open sand, $38 \%$ herbaceous vegetation, and $23 \%$ woody vegetation.

In a few instances, nesting has been observed in locations other than on sandbars. Keiser (2000) observed a female attempting to nest on a road bed approximately $20 \mathrm{~m}$ from the Pearl River, and he also reported observations of females attempting to nest on shell roads and in large, mowed grassy areas (Keiser 1994).

Nesting takes place during daylight hours, with most before $1200 \mathrm{hrs}$. Nest sites are constructed primarily in fine sand at locations averaging approximately $37 \%$ canopy cover and usually within $1 \mathrm{~m}$ of vegetation. Nests are placed from less than one to over $60 \mathrm{~m}$ from the shoreline, and on average are located approximately $18 \mathrm{~m}$ from water. Temperatures within the nest cavities average approximately $27^{\circ} \mathrm{C}$ (Jones 2006). Nesting females are sometimes attacked by raccoons (Procyon lotor), which often eviscerate the turtles (Jones, pers. obs).

Selman et al. (2007) conducted sex hormone profiles for male and female $G$. oculifera from the Pearl River near Columbia, Marion County, Mississippi. Estrogen levels for females were bimodal, peaking in April and August, and became more basal during the summer. Males had higher levels of testosterone during August-October than during the rest of the year.

Eggs, Clutch Size, Fecundity, and Incubation. - Graptemys oculifera eggs average $38.9 \mathrm{~mm}$ long by $22.7 \mathrm{~mm}$ wide and weigh $11.9 \mathrm{~g}$. The average clutch size is 3.66 , the modal clutch size is 3 , and clutch size ranges from 1 to 10 . Mean annual clutch frequency and mean annual egg production appear to be 1.10 and 4.03 , respectively. Some females may not reproduce every year, but most appear to produce at least one clutch per year, some produce two clutches, and at least a few females may produce three clutches in a year. Incubation, defined as the time between egg deposition and pipping, averages approximately 64 days in natural nests. Hatchlings remain in the nest chamber on average an additional 12 days, so the period between deposition and emergence of the hatchlings averages 76 days.

Nesting Success and Nest Predation. - The average number of nests destroyed by predators is approximately $86 \%$, with raccoons (Procyon lotor), armadillos (Dasypus novemcinctus), and fish crows (Corvus ossifragus) as the primary predators. Clutches that survive nest predation are vulnerable to predation from invertebrates, which may or may not destroy the entire clutch. Almost $24 \%$ of eggs or hatchlings not taken by vertebrate predators were destroyed by the ant species Solenopsis molesta, a native species related to the imported red fire ant, and Tripanurga importuna, a sarcophagid fly (Jones 2006).

Diet. - Kofron(1991) found that the diet of G.oculifera was composed primarily of insects, including caddisflies, diptera, mayflies, and beetles. Adult females have also been observed scavenging dead fish (Jones, pers. obs.).

Population Status. - McCoy and Vogt (1980) surveyed the Pearl River for G.oculifera in Mississippi and Louisiana, and concluded that the species was not threatened at that time. They indicated, however, that habitat quality and turtle populations should be carefully monitored, particularly with respect to declining water quality in the Pearl River. They designated two areas as "critical" for survival of the species. 
The first, upstream of Ross Barnett Reservoir, was 20 river miles $(32 \mathrm{~km}$ ) above and below Carthage, Leake County, and the second, downstream of Ross Barnett Reservior, was from Georgetown (Copiah County) to Bogalusa, Louisiana. The U.S. Fish and Wildlife Service (1986a) surveyed parts of the Pearl River in 1984 and 1985 and concluded that populations of G. oculifera were stable above Ross Barnett Reservoir but were declining downstream of the reservoir. Jones and Hartfield (1995) estimated population sizes using mark-recapture and basking surveys at five sites on the Pearl River in Mississippi. Their mark-recapture estimates showed densities ranging from over 340 to less than 90 ringed map turtles per river $\mathrm{km}$, and basking surveys ranging from 10-98 turtles per $\mathrm{km}$. The highest and lowest densities from mark-recapture estimates were both above Ross Barnett Reservoir. Lindeman (1998) conducted basking surveys for G. oculifera at several sites on the Pearl River and its tributaries, and found densities ranging from 2.5 to over 50 turtles per $\mathrm{km}$, with a mean density of 23.6 turtles per km. Shively (1999) surveyed the Bogue Chitto River in Louisiana, and estimated densities from basking surveys of 4-53 turtles per $\mathrm{km}$.

Both basking and mark-recapture surveys have been conducted at five sites (Jones and Hartfield 1996) sites on the Pearl River over the last 20 years. Populations at some of these sites have been relatively stable, but declines have occurred at others (Jones, unpubl. data).

Threats to Survival. - Over $21 \%$ of the range of $G$. oculifer $a$ had already been modified by channelization and the construction of dams when the species was initially considered for federal listing, and other construction projects were planned or authorized, which would have impacted an additional $28 \%$ of the Pearl River (U. S. Fish and Wildlife Service 1986a). There was also an authorized channelization project for over 100 river miles $(161 \mathrm{~km})$ of the Bogue Chitto River, which would have eliminated the river as suitable habitat for the turtle (U.S. Fish and Wildlife Service 1986a). Although many of these projects have not been constructed, and some are no longer under consideration, most are still authorized and may be initiated if funding becomes available.

Additional threats to the species are sedimentation from watershed structures and drainage ditches constructed by the U.S. National Resources Conservation Service (formerly the Soil Conservation Service; U.S. Fish and Wildlife Service 1986a) and river channel erosion from sand and gravel mining (U.S. Fish and Wildlife Service 2002). There is also evidence that shooting (Shively 1999), collection for the pet trade (U.S. Fish and Wildlife Service 2002), incidental take in hoop nets or on trot lines (Jones, pers. obs), and disturbance of both nesting (Jones 2006) and basking (Shively 1999) $G$. oculifera by recreational boaters and campers occur and are minor threats to this species. The major nest predators of G. oculifera are raccoons, armadillos, and fish crows. These three species have all been increasing in numbers within the range of the ringed map turtle over the last few years, and could have a significant impact on recruitment in the future (Jones 2006).
Conservation Measures Taken. - The ringed map turtle is listed as Threatened under the U.S. Endangered Species Act of 1973 (U.S. Fish and Wildlife Service 1986b), as Threatened by the State of Louisiana, and as Endangered by the State of Mississippi. A recovery plan has been prepared for the species (U.S. Fish and Wildlife Service 1988), but critical habitat has not been designated. The IUCN/SSC Tortoise and Freshwater Turtle Specialist Group (1989) Action Plan rating for G. oculifera was a 2, and the current IUCN Red List designation is Endangered (www.iucnredlist. org). The species is listed by CITES under Appendix III for the USA, covering all Graptemys spp. (www.cites.org/eng/ resources/species.html).

The ringed map turtle occurs in several protected areas, including the Nanih Waiya (Neshoba County), Pearl River (Madison County), and Old River (Pearl River County) Wildlife Management Areas in Mississippi, the Pearl River Wildlife Management Area (St. Tammany Parish) in Louisiana, and the Bogue Chitto National Wildlife Refuge (St. Tammany Parish, Louisiana and Pearl River County, Mississippi). All of these wildlife areas border the Pearl River but do not specifically manage for G. oculifera.

A ringed map turtle sanctuary approximately 19 river $\mathrm{km}$ in length was established by the Pearl River Valley Water Supply District (PRVWSD) in 1990 (U.S. Fish and Wildlife Service 2002). Management activities required of the PRVWSD include maintenance of informational signs to make the public aware of the sanctuary and to conduct channel maintenance consistent with proper management of the species (U.S. Fish and Wildlife Service 2002). As of 2008, however, at least one of the informational signs at a boat landing had been removed.

Conservation Measures Proposed. - Graptemys oculifera is currently listed on the IUCN Red List as Endangered, and even though it appears to be one of the most abundant turtles in the Pearl (23.6 basking turtles/km, Lindeman 1998) and Bogue Chitto (4-53 basking turtles/ $\mathrm{km}$, Shively 1999) rivers, it should still be retained at its current status because of its extremely restricted geographic distribution. The Pearl River is ca. $790 \mathrm{~km}$ in length and the Bogue Chitto River from the Mississippi-Louisiana border to the Pearl River (the known range of G. oculifera in the Bogue Chitto) is ca. $85 \mathrm{~km}$ in length. As this species is not commonly found in the smaller tributaries of these two rivers, the majority of $G$. oculifera occur in approximately $875 \mathrm{~km}$ of the Pearl and Bogue Chitto rivers combined. Assuming that both these rivers average approximately 100 $\mathrm{m}$ wide (an overestimate) and that the ringed map turtle occurs in the entire $875 \mathrm{~km}$ of these two rivers (which it does not), then the maximum area occupied by this species is ca. $87.5 \mathrm{~km}^{2}$. In addition, Ross Barnett Reservoir serves as a barrier to both up- and downstream movement of the species, effectively fragmenting G. oculifera into upper and lower Pearl River populations, and the quality of habitat in the Pearl River, and presumably also in the Bogue Chitto River (Shively 1999) has and will continue to deteriorate. 
The recovery plan for this species (U.S. Fish and Wildlife Service 1988) proposed that two segments of the Pearl River totaling at least 150 river miles $(240 \mathrm{~km})$ be protected as habitat for G. oculifera, either through acquisition or by regulation, and that turtle densities be monitored in these areas at three-year intervals. However, mechanisms for funding these activities were not proposed. The recovery plan also recommended a series of conservation-oriented studies, including but not limited to characterizing physical habitat, dietary studies, determining population structure, reproductive parameters, and daily and seasonal movements. Some of these studies have already been completed (e.g., Jones and Hartfield 1995; Shively 1999; Jones 2006), but others have not.

Captive Husbandry. - Wahlquist (1970) briefly described the conditions in which he kept Graptemys, including G. oculifera. Turtles were kept outside except during cold weather, and were fed a diet of lean ground beef, boiled crayfish, shrimp, cut whole fish, insects, and a calcium source without additives. The ringed map turtle has been kept successfully by public aquaria, such as the Tennessee Aquarium and the Mississippi Museum of Natural Science, for several years, where they have bred successfully.

Current Research. - Much of the research on G.oculifera over the last 15 years has been stimulated by its inclusion on the U.S. list of threatened and endangered species. Research currently underway includes continued monitoring of the five sites established by Jones and Hartfield (1995) to determine changes in population size, survivorship, and growth over time, and to examine the population genetics of the species, specifically with reference to the impact of the Ross Barnett Reservoir. Future research that would be useful for management of this species includes dietary studies, survivorship of hatchlings after leaving the nesting beaches, and home range and movements. Additional research on any aspects of the biology of this species in the Bogue Chitto River in Louisiana would be useful for comparison with the Pearl River populations.

Acknowledgments. - Partial funding for much of the research on this species by both authors was provided by the U.S. Fish and Wildlife Service, Project E-1, under a Section 6 Cooperative Agreement with the Mississippi Department of Wildlife, Fisheries, and Parks.

\section{LITERATURE CITED}

BAUR, G. 1890. Two new species of tortoises from the South. Science 16:262-263.

BAUR, G. 1893. Two new species of North American Testudinata. The American Naturalist 27:675-677.

Buhlmann, K., Tuberville, T., and Gibbons, W. 2008. Turtles of the Southeast. The University of Georgia Press, Athens, Georgia, $252 \mathrm{pp}$.

Buhlmann, K.A., Akre, T.S., Iverson, J.B., Karapatakis, D., MitTERMEIER,R.A.,GeORgES,A.,RHODIN,A.G.J., vANDiJK,P.P., AND GiBBons, J.W.In press. A global analysis of tortoise and freshwater turtle distributions withidentification of priority conservation areas.
Chelonian Conservation and Biology 8(2):in press.

CAGLE, F.R. 1952. The status of the turtles Graptemys pulchra Baur and Graptemys barbouri Carr and Marchand, with notes on their natural history. Copeia 1952:223-234.

CAGLE,F.R. 1953. The status of the turtle Graptemys oculifera (Baur). Zoologica 38:137-144.

Cagle, F.R. 1954. Two new species of the genus Graptemys. Tulane Studies in Zoology 1:167-186.

CARr, A. 1949. The identity of Malacoclemmys kohnii Baur. Herpetologica 5:9-10.

Dickerson, D.D. And Reine, K.J. 1996. Habitat Assessment and Relative Abundance Estimates for the Ringed Sawback Turtle (Graptemys oculifera) in Dredging Sites of the West Pearl River Navigation Project (Louisiana). U.S. Army Engineer District, Vicksburg, Mississippi, 21 pp.

DobIE, J.L. 1981. The taxonomic relationship between Malaclemys Gray, 1844 and Graptemys Agassiz, 1857(Testudines:Emydidae). Tulane Studies in Zoology and Botany 23:85-102.

Dundee, H.A. and Rossman, D.A. 1989. The Amphibians and Reptiles of Louisiana. Louisiana State University Press, Baton Rouge, Louisiana, 300 pp.

ERnst, C.H. ANd Barbour, R.W. 1989. Turtles of the World. Smithsonian Institution Press, Washington, D.C., 313 pp.

ERnst, C.H., Lovich, J.E. AND Barbour, R.W. 1994. Turtles of the Unites States and Canada. Smithsonian Institution Press, Washington, D.C., 578 pp.

ERNST, C.H. AND Lovich, J.E. 2009. Turtles of the United States and Canada, Second Edition. The John Hopkins University Press, Baltimore, Maryland, $827 \mathrm{pp}$.

IVERSON,J.B. 1992.ARevised Checklist with Distribution Maps of the Turtles of the World. Richmond, IN: Privately printed, 363 pp.

Jones, R.L. 2006. Reproduction and nesting of the endangered ringed map turtle, Graptemys oculifera, in Mississippi. Chelonian Conservation and Biology 5:195-209.

Jones, R.L. ANd HaRTFIELD, P.D. 1995. Population size and growth in the turtle Graptemys oculifera. Journal of Herpetology 29:426-436.

KeISER, E.D. 1994. A Summer Survey of Amphibians, Reptiles, and Mammals within Designated WesternAcreage of the Stennis Space Center,Hancock County, Mississippi.Final Report.NASA/Lockheed Stennis Space Center, Picayune, Mississippi, 197 pp.

KeISER, E.D. 2000. A Survey on the Nanih Waiya Wildlife Management Area to Locate Turtles and Turtle Nesting Sites, with Emphasis on the Ringed Map Turtle (Graptemys oculifera). Mississippi Department of Wildlife, Fisheries, and Parks, Jackson, Mississippi, 92 pp.

KilLEBrew, F.C. 1979. Osteological variation between Graptemys flavimaculata and Graptemys nigrinoda (Testudines: Emydidae). Herpetologica 35:146-153.

Kofron, C.P. 1991. Aspects of ecology of the threatened ringed sawback turtle, Graptemys oculifera. Amphibia-Reptilia 12:161-168.

Lamb, T., Lydeard, C., WalKer, R.B., and GibBons, J.W. 1994. Molecular systematics of map turtles (Graptemys): a comparison of mitochondrial restriction site versus sequence data. Systematic Biology 43:543-559.

LindeMAN, P.V. 1998. Of deadwood and map turtles (Graptemys): an analysis of species status for five species in three river drainages using replicated spotting-scope counts of basking turtles. Linneaus Fund Research Report. Chelonian Conservation and Biology 3:137-141.

LiNDEMAN,P.V. 1999. Surveys of basking map turtles Graptemys spp. in three drainages and the importance of deadwood abundance. 
Biological Conservation 88:33-42.

McCoy, C.J. AND R.C. Vogt. 1980. Distribution and Population Status of the Ringed Sawback Graptemys oculifera (Baur) in Mississippi and Louisiana. Final Report, U.S. Fish and Wildlife Service contract number 14-16-0004-79-038.

McCoy, C.J. And R.C. Vogt. 1988. Graptemys oculifera. Catalog of American Amphibians and Reptiles 442:1-2.

MCDowell, S.B. 1964. Partition of the genus Clemmys and related problems in the taxonomy of the aquatic Testudinidae.Proceedings of the Zoological Society of London 143:239-279.

Selman, W., Qualls, C., And Mendonca, M. 2007. Assessment of the impact of Hurricane Katrina on the yellow-blotched sawback (Graptemysflavimaculata): Year 1.Technical Report submitted to the U.S. Fish and Wildlife Service, Jackson, Mississippi, 73 pp.

ShIVELY, S.H. 1999. 1999 Survey for the Ringed Map Turtle (Graptemys oculifera) in the Bogue Chitto River, Louisiana, Louisiana E-1-9. Department of Wildlife and Fisheries, Baton Rouge, Louisiana, $12 \mathrm{pp}$.

STEJNEGER,L. AND BARBOUR,T. 1933.ACheck List of North American Amphibians and Reptiles, 3rd Edition. Harvard University Press, Cambridge, Massachusetts, 185 pp.

STEJNEGER,L. AND BARBOUR,T. 1939.ACheck List of North American Amphibians and Reptiles, 4th Edition. Harvard University Press, Cambridge, Massachusetts, 207 pp.

U.S.FISH AND WILDLIFESERVICE. 1986a.Proposed threatened status for the ringed sawback turtle. Federal Register 51(13):2741-2744.

U.S. Fish and WildLIFE SeRvice. 1986b. Determination of threatened status for the ringed sawback turtle. Federal Register 51(246):45907-45910.

U.S.FISH AND WILdLIFE SERVICE. 1988. Recovery Plan for the Ringed Sawback Turtle, Graptemys oculifera. U.S. Fish and Wildlife Service, Atlanta, Georgia, 28 pp.

U.S.Fish AND WILDLIFESERVICE. 2002.Ringed Map Turtle(Graptemys oculifera) 5-Year Review: Summary and Evaluation. U.S. Fish and Wildlife Service, Mississippi Ecological Services Office, Jackson, Mississippi, 10 pp.

WAHLQUIST,H. 1970.Sawbacks of the Gulf coast.International Turtle and Tortoise Society Journal 4:10-13, 28.

\section{Citation Format for this Account:}

Jones, R.L. And Selman, W. 2009. Graptemys oculifera (Baur 1890) - ringed map turtle, ringed sawback. In: Rhodin, A.G.J., Pritchard, P.C.H., van Dijk, P.P., Saumure, R.A., Buhlmann, K.A., Iverson, J.B., and Mittermeier, R.A. (Eds.). Conservation Biology of Freshwater Turtles and Tortoises: A Compilation Project of the IUCN/SSC Tortoise and Freshwater Turtle Specialist Group. Chelonian Research Monographs No. 5, pp. 033.1-033.8, doi:10.3854/crm.5.033.oculifera.v1.2009, http:// www.iucn-tftsg.org/cbftt/. 